\title{
ВЛАДИМИР КОНСТАНТИНОВИЧ КОВЫЛОВ (23. 02.1937 - 14.04.2018)
}

\author{
Р. Е. Рогозина \\ Воронежский государственныгй университет, Россия \\ Поступила в редакцию 6 марта 2019 г.
}

\begin{abstract}
Аннотация: Статья посвящена памяти ученого, исследователя, руководителя студенческой науки, организатора учебных практик и туристических походов, педагога Владимира Константиновича Ковылова, прошедшего на факультете географии, геоэкологии и туризма ВГУ путь от преподавателя до ведущего доцента кафедры социально-экономической географии и регионоведения.

Ключевые слова: преподаватель, научный руководитель, студенческая научно-исследовательская работа, комплексная межзональная полевая географическая практика, научные публикации, прогнозирование, районирование, общественная работа.
\end{abstract}

\section{Vladimir Konstantinovitch Kovylyov (23.02.1937 - 14.04.2018) \\ R. Ye. Rogozina}

\begin{abstract}
The article is dedicated to the memory of a scientist, researcher, leader of student science, organizer of educational practices and tourist trips, pedagogue Vladimir Konstantinovitch Kovylyov, who went from the teacher to the leading associate professor of the Socio-Economic Geography and Regional Studies department at the faculty of Geography, Geoecology and Tourism.
\end{abstract}

Key words: teacher, research supervisor, student research work, complex interzonal geographical field practice, scientific publications, forecasting, zoning, social work.

Владимир Константинович Ковылов родился в районном поселке Таловая Таловского района Воронежской области, в семье служащих. Мама Васильченко Ольга Николаевна, 1916 года рождения, работала в Воронежском отделе спецсвязи. Отец - Ковылов Константин Иванович не жил с семьей с 1938 года.

С 1944 по 1954 год Владимир Константинович учился в средней мужской школе № 7 города Воронежа. После ее окончания в течение нескольких месяцев работал коллектором Украинского отделения Всесоюзного научно-исследовательского геологического нефтяного института (Укр.ВНИГНИ).

В 1955 году он поступил на 1 курс естественно-географического факультета Воронежского государственного педагогического института (ВГПИ) и в 1960 году успешно окончил его, получив квалификацию учителя биологии и географии средней школы. В соответствии с государственным

(C) Рогозина Р.Е., 2019 распределением 2 года отработал в Новосибирской области в школе № 3 города Татарска в должности учителя химии и биологии.

С 1962 по 1965 год обучался в аспирантуре при кафедре экономической географии Воронежского государственного педагогического института у доцента Николая Ивановича Коржова и после ее окончания работал в течение года на кафедре ассистентом. Затем, в связи с трагическими событиями, не позволившими ему завершить диссертацию (гибелью доцента Н.И. Коржова), перешел в Воронежский государственный университет (ВГУ), где работал под руководством профессора Григория Терентьевича Гришина. С 01.10.1966 года и до ухода на заслуженный отдых 01.02.2007 года (около 41 года) Владимир Константинович трудился на кафедре экономической географии ВГУ. Свою деятельность в стенах этого вуза он начал с должности преподавателя. Но уже через четыре года, защитив в Московском государственном университете диссертацию на тему «Экономическое мик- 
рорайонирование района с аграрно-индустриальным типом развития (на примере Аннинского Прибитюжья)», и получив степень кандидата географических наук (1970 г.), он стал старшим преподавателем. В 1973 году В. К. Ковылов был утвержден в звании, а с сентября этого же года был назначен на должность доцента кафедры экономической географии ВГУ.

Научные интересы этого периода совпадали с научными исследованиями кафедры: экономическое микрорайонирование, география промышленности ЦЧР, перспективы освоения Белгородского железорудного района КМА, производственная и территориальная структура Центрального промышленного подрайона Липецкой области. Занимаясь этими проблемами, а также поиском новых мест для проведения учебных практик студентов вместе с сотрудниками кафедры, Владимир Константинович выезжал в командировки для знакомства с объектами исследования: областные центры ЦЧЭР, Старооскольский район Белгородской области, город Губкин, административные районы Воронежской области. Результатом научной деятельности этого периода были свыше 50 опубликованных научных работ и несколько отчетов для служебного пользования.

Будучи членом КПСС, в начале 80-х годов (1980-1982 гг.) он прошел обучение в Университете марксизма-ленинизма Воронежского обкома партии и получил высшее политическое образование. Затем, в течение целого ряда лет являлся внештатным лектором Высшей партийной школы при Воронежском обкоме КПСС, посещая с выступлениями предприятия и организации города и области. В течение 18 лет избирался партгруппоргом кафедры экономической географии, членом и секретарем партийного бюро факультета.

Много сил и внимания В.К. Ковылов отдавал своей основной работе - преподавателя, воспитателя. Он был Учителем с большой буквы. Его постоянно окружали студенты - в перерывах между лекциями, после занятий. Он всегда находил для них время. Этому способствовало и то, что он вел со студентами большую научно-исследовательскую работу. В течение 5 лет (1971-1976 гг.) руководил факультетской школой Юных географов (школа «ЮНГ»). Затем, чуть позже, с 1980 по 1987 год Владимир Константинович был организатором и научным руководителем студенческой научно-исследовательской лаборатории (СНИЛ) «Географ» «Синильга». Под лабораторию силами студентов была оформлена аудитория №313, был сделан стенд с логотипом лаборатории, который постоянно обновлялся; ежегодно проводилась отчетная конференция СНИЛ и даже была отдельная секция СНИЛ «Географ» на ежегодной отчетной факультетской сессии; осуществлялись студенческие полевые экспедиции (по городам ЦЧР). СНИЛ выполняла хоздоговорную работу с ЦЭНИИ при Госплане РСФСР «Перспективы развития Железногорского промышленного узла до 2000 года». С 1983 года и сам Владимир Константинович, и лаборатория стали работать по госбюджетной теме «Топливно-энергетический комплекс ЦЧЭР» долгосрочное прогнозирование. По результатам исследований лаборатории готовились отчеты, которые передавались заказчику, защищались курсовые и дипломные работы, члены СНИЛ принимали участие в конференциях молодых ученых и специалистов ВГУ. Заведующий кафедрой, профессор Ю. В. Поросенков в своей статье о сотрудниках кафедры так написал об этой деятельности В. К. Ковылова: «Ему принадлежит приоритет на кафедре и факультете в формировании уникальной системы научно-исследовательской работы студентов на основе специальных творческих коллективов» [1]. Ни до, ни после Владимира Константиновича, такая работа в таких масштабах на факультете не велась.

В течение 21 года В.К. Ковылов руководил комплексной полевой межзональной географической практикой в разных районах страны и дважды в Югославии (Македония - Скопье). Страна была большая, и это были территории Украины, Казахстана, республик Средней Азии, Урала. Особенно Владимир Константинович любил Среднюю Азию - Тянь-Шань. Прежде, чем отправиться в путь им проводилась большая подготовительная работа: разрабатывались маршруты, графики движения, сметы, программы. А потом осенью в начале учебного года устраивались своеобразные неформальные отчеты студентов о состоявшейся практике: студенты собирались в аудитории 313 (СНИЛ «Географ») или любой другой, в общежитии и вспоминали летние походы в горы, экскурсии на предприятия, пересматривали фотографии и слайды, полевые дневники. Часто эти походы осуществлялись совместно со студентами из педагогического института, связь с которым Владимир Константинович не терял на протяжении всей своей жизни. Студенты возвращались с практик с новыми песнями и стихами собственного сочинения, которые по заданию руководителя они должны были написать на основе своих впечатлений. 
Интерес к путешествиям, необходимые знания и опыт, а также большой архив маршрутов и картографического материала способствовали тому, что он много лет был членом маршрутно-квалификационной команды при Воронежском городском «Клубе туристов и альпинистов». За время активной туристской деятельности Владимир Константинович совершил 43 крупных категорийных путешествия, большую часть из них - вместе со студентами. В 1965 году ему было присвоено звание «Мастер туризма СССР». Значок, свидетельствующий об этом, он все время носил на лацкане пиджака.

Основные направления научно-исследовательской работы В. К. Ковылова с середины 70-х годов и до окончания трудовой деятельности в ВГУ связаны со следующей тематикой: «Проблемы территориальной организации промышленности областей КМА»; «Географические исследования территориальной структуры промышленности основного социально-экономического района»; «Методология и методика географического исследования крупногородских агломераций как ядер территориальной структуры промышленных комплексов основного социально-экономического района» (тема разрабатывалась совместно с учеными ГДР (1979-1983 гг.); «Топливно-энергетический комплекс» Комплексной программы научно-технического прогресса ЦЧЭР на 1986-2005 гг. (руководитель и исполнитель раздела); «Ядерная энергетика, вопросы развития военно-промышленного комплекса»; «Социально-экономическое районирование Воронежской области»; «Вопросы истории Воронежской географической школы».

За время работы в ВГУ Владимиром Константиновичем были освоены основные курсы, читаемые на кафедре экономической географии: «Экономическая и социальная география СССР/Pocсии»; «География промышленности СССР/Pocсии»; «Методика преподавания географии в школе»; «Теоретические основы экономического и социально-экономического районирования»; «Технико-экономические основы производства»; «Территориальное планирование и районная планировка» и другие.

Студенты, умевшие чертить и рисовать, помогли Владимиру Константиновичу создать серьезную учебную коллекцию графических наглядных пособий по основным читаемым курсам (их было более 200), которой он очень гордился. Привычной была картина, когда Владимир Константинович шел в аудиторию на занятия, а рядом с ним шли несколько студентов и несли свернутые в рулоны наглядные пособия по этим курсам, потому что одному человеку их было сложно унести. В личном деле в характеристике начала его педагогической работы в вузе записано: «особенно положительной оценки заслуживает то, что Ковылов В.К. творчески подходит к сбору материала и методическому оформлению лекций и практических занятий». И эту способность он не утратил до конца своей деятельности.

Владимир Константинович был щедрым человеком и с удовольствием делился своими знаниями и опытом с молодыми коллегами, которых он приглашал на свои занятия, особенно тех, кто вместе с ним работал на одном учебном курсе. Он считал, что в этом случае должно сохраняться единообразие и определенная преемственность.

Основные публикации Владимира Константиновича были связаны с его научными интересами и тематикой исследований кафедры. Он принимал участие в написании кафедральных монографий: «Проблемы территориальной организации производительных сил Центрально-Черноземного района» (1977 г.), где были написаны 2 главы: «Промышленность» и «Внутрирайонные комплексы»; в монографии «Территориальная структура основного социально-экономического района (Вопросы теории)» (1985 г.) - глава «Методология и методика географического исследования территориальной структуры промышленности основного социально-экономического района»; в монографии «Народно-хозяйственный комплекс ЦЧЭР: пути совершенствования» (1989 г.) он был автором главы «Концепция перспективного развития ТЭК ЦЧР». В 2004 году совместно с профессором Пермского государственного университета М. Д. Шарыгиным было опубликовано учебное пособие «Регионоведение» (2004 г.), в котором нашли отражение многолетние исследования авторов в области районообразования, районирования территорий разных уровней. Вопросы формирования экономических районов дробного уровня как социально-экономических систем всегда находились в поле зрения Владимира Константиновича, начиная с момента его работы над своей кандидатской диссертацией.

В. К. Ковыловым изданы многочисленные методические разработки по всем читаемым им дисциплинам. Он считал своим долгом готовить такие материалы в помощь студентам, которые они могли бы использовать при освоении новых курсов. Им были опубликованы многочисленные ста- 
тьи и тезисы в материалах конференций и различных сборниках (всего около 200 работ).

«В последние годы в своих публикациях попытался воздать должное своим Учителям - писал он в одной из своих статей. Вслед за Ю. Г. Саушкиным попытался наполнить конкретным содержанием и лицами «Воронежское географическое гнездо», обосновать творческую связь с москвичами, петербуржцами, пермяками, украинцами, кубанцами, с деятелями кавказской и среднеазиатской географии».

В статье «Восхищение своими дипломниками - географами» вышедшей в Вестнике Воронежского отделения Русского географического общества, Владимир Константинович как истинный экономико-географ со свойственной ему скрупулезностью подсчитал, что за годы его работы в ВГУ он руководил 168 дипломными работами, авторы которых защитили их - на «отлично» - 118 (70,2\%), «хорошо» - 38 (22,7\%), «удовлетворительно» $12(7,1 \%)$. Под его руководством в научно-студенческих, научных конференциях прозвучало 170 докладов, опубликовано 133 студенческие статьи [2].

Преподавательская, научно-исследовательская деятельность В.К. Ковылова сопровождалась активной общественной работой. Он был членом правления, председателем секции наук о Земле естественно-научного НМС; членом аттестационной комиссии Воронежской областной организации общества «Знание»; членом Ученого Совета Воронежского отделения Русского географического общества СССР; членом методического совета по географии Воронежского института усовершенствования учителей (ИУУ), консультантом отдела территориальных исследований ОЭУ НИЧ ВГУ.

Уйдя на заслуженный отдых, В. К. Ковылов не потерял интерес к науке и исследованиям. Он принимал участие в конференциях ВГПИ, писал отзывы на авторефераты диссертаций соискателей различных научных степеней, всегда живо откликался на предложения принять участие в заседаниях научного общества учащихся (НОУ) на родном факультете.

Если говорить о человеческих качествах, то Владимир Константинович был человеком обязательным, ответственным и очень требовательным, в первую очередь - к себе, а потом и ко всем окружающим, включая студентов. Они это знали, ценили, и отвечали тем же. В них жила уверенность, что посещать его занятия нужно обязательно, сда- вать экзамены будет трудно, но если выполнять все его требования, то это - вполне реально.

Владимир Константинович был творческой личностью: пел, играл на гитаре и сочинял стихи, будучи студентом ВГПУ, играл в институтском театре. А сотрудников кафедры и факультета он баловал своими сочинениями к различным праздничным датам. К своим коллегам он относился с большим уважением и теплотой, сформулировав свое видение коллектива факультета, как единой системы: «Профессоров, доцентов, ассистентов, преподавателей, аспирантов, лаборантов кафедр, служащих деканата и научных подразделений факультета и студентов всех курсов и специальностей рассматриваю как единый целостный животворящий организм, как единую сложную научнообразовательную социальную систему» [2].

В одной из своих последних статей Владимир Константинович высказал пожелание начинающим ученым, аспирантам, студентам, которое должно определять их перспективы: «Молодым и ищущим последний и истинно азиатский совет: вера в свое будущее без дел мертва и вам на выбор есть три пути: долгий - путь знания, короче - путь веры, самый короткий - путь действия. Дерзайте, действуйте и обрящите!» [2].

Есть выражение, ставшее крылатым: «Человек жив до тех пор, пока жива о нем память». Думается, что память о Владимире Константиновиче еще долго будет жива в сердцах его друзей, коллег и огромной армии бывших студентов.

\section{СПИСОК ЛИТЕРАТУРЫ}

1. Гришин Г. Т. Кафедра социально-экономической географии и регионоведения: история и современность / Г. Т. Гришин, Ю. В. Поросенков // Вестник Воронежского государственного университета. Сер. География. Геоэкология. - 2004. - № 2. - С. 42-62.

2. Ковылов В. К. Восхищение своими дипломниками-географами / В. К. Ковылов // Вестник Воронежского отделения Русского географического общества : сборник научных трудов. - 2010. - Т. 10. - С. 215-220.

\section{REFERENCES}

1. Grishin G. T. Kafedra sotsial'no-ekonomicheskoy geografii i regionovedeniya: istoriya i sovremennost' / G. T. Grishin, Yu. V. Porosenkov // Vestnik Voronezhskogo gosudarstvennogo universiteta. Ser. Geografiya. Geoekologiya. - 2004. - № 2. - S. 42-62.

2. Kovylov V. K. Voskhishchenie svoimi diplomnikami-geografami / V. K. Kovylov // Vestnik Voronezhskogo otdeleniya Russkogo geograficheskogo obshchestva : sbornik nauchnykh trudov. -2010 . - T. 10. - S. 215-220. 


\section{Рогозина Римма Евгеньевна}

кандидат географических наук, доцент кафедры геоэкологии и мониторинга окружающей среды факультета географии, геоэкологии и туризма Воронежского государственного университета, г. Воронеж, т. (473)266-56-54, E-mail: rrogozina@bk.ru
Rogozina Rimma Yevgen'yevna

Candidate of Geographical Sciences, Associate Professor of the Department of Geoecology and Environmental Monitoring, Faculty of Geography, Geoecology and Tourism, Voronezh State University, Voronezh, tel. (473)266-56-54, E-mail: $\underline{\text { rrogozina@bk.ru }}$ 